\title{
Invasion genetics of the mummichog (Fundulus heteroclitus): recent anthropogenic introduction in Iberia
}

Teófilo Morim $^{1}$ ， Grant R Bigg ${ }^{2}$ ， Pedro M Madeira ${ }^{1}$ ， Jorge Palma ${ }^{1}$, David D Duvernell ${ }^{3}$, Enric Gisbert ${ }^{4}$, Regina L Cunha ${ }^{1}$, Rita Castilho ${ }^{\text {Corresp. } 1}$

${ }^{1}$ Centre for Marine Sciences (CCMAR), University of Algarve, Faro, Portugal

2 Department of Geography, University of Sheffield, Sheffield, United Kingdom

3 Department of Biological Sciences, Missouri University of Science and Technology, Rolla, Missouri, United States of America

4 RTA, Sant Carles de la Ràpita, Spain

Corresponding Author: Rita Castilho

Email address: rita.castil@gmail.com

Human activities such as trade and transport have increased considerably in the last decades, greatly facilitating the introduction and spread of non-native species at a global level. In the Iberian Peninsula, Fundulus heteroclitus, a small euryhaline coastal fish with short dispersal, was found for the first time in the mid-1970s. Since then, $F$. heteroclitus underwent range expansions, colonizing the southern region of Portugal, southwestern coast of Spain and the Ebro Delta in the Mediterranean Sea. Cytochrome $b$ sequences were used to elucidate the species invasion pathway in Iberia. Three Iberian locations (Faro, Cádiz and Ebro Delta) and 13 other locations along the native range of $F$. heteroclitusin North America were sampled. Results revealed a single haplotype, common to all invasive populations, which can be traced to the northern region of the species' native range. We posit that the origin of the founder individuals is between New York and Nova Scotia. Additionally, the lack of genetic structure within Iberia is consistent with a recent invasion scenario and a strong founder effect. We suggest the most probable introduction vector is associated with the aquarium trade. We further discuss the hypothesis of a second human-mediated introduction responsible for the establishment of individuals in the Ebro Delta supported by the absence of adequate muddy habitats linking Cádiz and the Ebro Delta. Although the species has a high tolerance to salinity and temperature, ecological niche modelling indicate that benthic habitat constraints prevent along-shore colonisation suggesting that such expansions would need to be aided by human release. 
1 Invasion genetics of the mummichog (Fundulus heteroclitus): recent anthropogenic

2 introduction in Iberia

3

4

5 Teófilo Morim ${ }^{1}$, Grant R. Bigg ${ }^{2}$, Pedro M. Madeira ${ }^{1}$, Jorge Palma ${ }^{3}$, David D. Duvernell ${ }^{4}$, Enric

6 Gisbert $^{5}$, Regina L. Cunha ${ }^{1}$, and Rita Castilho*1

7

$8{ }^{1}$ Centre for Marine Sciences (CCMAR), University of Algarve, Campus de Gambelas, Faro

9 8005-139, Portugal.

102 Department of Geography, University of Sheffield, Winter Street, Sheffield S10 2TN, UK.

$11{ }^{3}$ Department of Biological Sciences, Missouri University of Science and Technology, Rolla,

12 Missouri 65409, USA

$13{ }^{4}$ RTA - Sant Carles de la Ràpita, Crta Poble Nou km 5.5, P.O. Box 200, 43540 Sant Carles de la 14 Ràpita, SPAIN

15

16

$17 *$ Corresponding author:

18 Email: rcastil@ualg.pt

19 Telephone: +351918397282

20

21 Runing head: invasive Iberian mummichog

22

23

24 


\section{Abstract}

26 Human activities such as trade and transport have increased considerably in the last decades,

27 greatly facilitating the introduction and spread of non-native species at a global level. In the

28 Iberian Peninsula, Fundulus heteroclitus, a small euryhaline coastal fish with short dispersal, was

29 found for the first time in the mid-1970s. Since then, F. heteroclitus underwent range

30 expansions, colonizing the southern region of Portugal, southwestern coast of Spain and the Ebro

31 Delta in the Mediterranean Sea. Cytochrome $b$ sequences were used to elucidate the species

32 invasion pathway in Iberia. Three Iberian locations (Faro, Cádiz and Ebro Delta) and 13 other

33 locations along the native range of $F$. heteroclitus in North America were sampled. Results

34 revealed a single haplotype, common to all invasive populations, which can be traced to the

35 northern region of the species' native range. We posit that the origin of the founder individuals is

36 between New York and Nova Scotia. Additionally, the lack of genetic structure within Iberia is

37 consistent with a recent invasion scenario and a strong founder effect. We suggest the most

38 probable introduction vector is associated with the aquarium trade. We further discuss the

39 hypothesis of a second human-mediated introduction responsible for the establishment of

40 individuals in the Ebro Delta supported by the absence of adequate muddy habitats linking Cádiz

41 and the Ebro Delta. Although the species has a high tolerance to salinity and temperature,

42 ecological niche modelling indicate that benthic habitat constraints prevent along-shore

43 colonisation suggesting that such expansions would need to be aided by human release. 


\section{Introduction}

45 As a consequence of human activities involving large distance marine transportation and trade,

46

47

48

49

50

51

52

53

54

55

56

57

58

59

60

61

62

63

64

65

66

67

68

69

70

71

72

73

74

worldwide marine biological invasion rates have increased dramatically in the last 30 years (e.g., Hulme 2009). Along the European coasts, there are reports of over 850 invasive species of which, 237 occur along the eastern Atlantic coastal areas, 680 in the Mediterranean Sea and the remaining in the Baltic (Galil et al. 2014). Marine invasive species pose a significant environmental threat as they are recognized as one of the major drivers of biodiversity loss (Millennium Ecosystem Assessment 2005), altering ecosystems and their dynamics, shifting the community structure and displacing endemic species (Molnar et al. 2008). Negative impacts may also be registered at the economic and social levels, affecting fisheries, aquaculture, tourism or human health (Bax et al. 2003). Invasive species spread and occupy new marine and coastal ecosystems through several maritime introduction vectors such as ballast water, biofouling of vessels, aquaculture escape or ornamental species trade (see Williams et al. 2013 and references therein).

Reconstructing the invasion pathways and identifying the putative source populations with historical and contemporary vector records is a difficult task (Estoup \& Guillemaud 2010; Lawson Handley et al. 2011). In this context, molecular genetic data is a powerful tool to reconstruct invasive history by identifying putative source populations and genetic bottlenecks (Bock et al. 2015; Cristescu 2015). Although genetic data does not always allow for successful identification of these processes, there are three conditions which increase the probability of accurate reconstruction of the invasive pathway: (1) extensive sampling along the native range to ensure all the putative source populations are known, (2) the presence of genetic structure in the native range to narrow down the putative source regions and (3) a short amount of time passed since the invasion so that processes such as genetic drift do not increase the genetic differentiation between native and invasive populations (Geller et al. 2010).

The advent of ecological niche modelling (ENM) has contributed to the building of environmental risk maps for biological invasion by allowing formal, quantitative, inclusion of varying environmental characteristics, both in space and time, to be added to such considerations. Such new approaches to invasion risk monitoring provide useful insights by predicting both potential colonization routes and the probability of new invasions occurring (Hulme 2009; Molnar et al. 2008). 
75

76

77

78

79

80

81

82

83

84

85

86

87

88

89

90

91

92

93

94

95

96

97

98

99

100

101

102

103

104

105

The mummichog, Fundulus heteroclitus (Linnaeus, 1766), is a small teleost naturally occurring almost continuously in saltmarshes of the North American east coast, from Newfoundland to Florida (Hardy Jr 1978). This species is extremely resistant to a wide range of salinities and temperatures, and can be found in freshwater, brackish or saltwater, inhabiting sheltered coastal areas such as saltmarshes, tidal creeks, estuaries or bays all year-round (Bigelow \& Schroeder 1953; Hardy Jr 1978). F. heteroclitus is one of the most stationary marine species (Bigelow \& Schroeder 1953), with short dispersal distances (1-2 km, Fritz et al. 1975), high site fidelity closely related to the presence of saltmarshes (Kneib 1984) and short home ranges (36-38 m, Lotrich 1975). Enzyme-coding loci (Powers \& Place 1978; Powers et al. 1986; Ropson et al. 1990), mitochondrial DNA (Bernardi et al. 1993; González-Vilaseñor \& Powers 1990; Smith et al. 1998), putative neutral nuclear microsatellite loci (Adams et al. 2006;

Duvernell et al. 2008), and a variety of nuclear single-nucleotide polymorphisms (see McKenzie et al. 2016 and references therein) demonstrated concordance of clinal patterns, where a break is placed between the meridians $40^{\circ}$ and $41^{\circ} \mathrm{N}$, along the coast of New Jersey. These studies concur with Morin and Able (1983), supporting the division into two subspecies: F. heteroclitus macrolepidotus (Walbaum, 1792)to the north of the cline and F. heteroclitus heteroclitus (Linnaeus, 1766) to the south of the cline.

In the Iberian Peninsula, F. heteroclitus was first detected in the 1970s, in the Guadalquivir and Guadiana saltmarshes (southwestern coast of Spain) (Hernando 1975) and in the Guadiana Delta (Coelho et al. 1976). More recently, its presence was also reported in the Ebro Delta, northeastern coast of Spain (Gisbert \& López 2007) and in the Ria Formosa, south of Portugal (e.g., Catry et al. 2006) where it can reach high densities (Gonçalves et al. 2017).The species was probably introduced between 1970 and 1973 in the Spanish saltmarshes (FernándezDelgado 1989) either involuntarily via aquarium trade (e.g. Elvira \& Almodóvar 2001), ballast water (Fernández-Delgado 2010; García-Revillo \& Fernández-Delgado 2009), or intentionally for purposes of biological control (Gozlan 2010). The Ebro Delta individuals were probably caught in the southern Spanish saltmarshes to be used in aquaculture and the aquarium trade (Gisbert \& López 2007) and were later released from captivity. Another possibility for the Ebro Delta introduction is an accidental escape from a research centre nearby, where this species had already been used as a scientific model (Gisbert \& López 2007). Two previous studies have analysed the origin of the southwestern Spanish populations using mitochondrial DNA 
106 (mtDNA), concluding the founder individuals were original from the northern native region

107 between Maine and Nova Scotia where the northern subspecies F. h. macrolepidotus is

108 distributed (Bernardi et al. 1995; Fernández-Pedrosa et al. 1996).

109 In the present study, we aim to build on previously published studies on the invasive

110 range of $F$. heteroclitus by using (1) more sampling locations (one in the Mediterranean Sea and

111 two locations in the eastern Atlantic, and thirteen native locations), (2) a significantly larger

112 number of individuals (248 in total), and (3) a three times larger fragment of the mitochondrial

113 DNA cytochrome $b$ gene; and to evaluate the genetic diversity and invasion pathways. Given

114 that the species was recently reported in the Iberian Peninsula and has a limited adult dispersal

115 capability, we tested the hypothesis of a human-mediated single Iberian introduction followed by

116 dispersal promoted along the main oceanographic currents. and we mapped the environments

117 compatible with the species' ecological requirements to evaluate the dispersion potential through

118 suitable continuous habitat. This hypothesis leads to the expectation of an Iberian invasion based

119 on a few founder individuals, with consequent lower genetic diversity than the putative identified

120 source population. Also, the Iberian populations are expected to show no evident genetic

121 structure given the short time since invasion.

122

123 Materials and methods

124 Sampling. A total of 248 Fundulus heteroclitus individuals from 16 locations: 13 sites in the

125 western Atlantic, one in the Mediterranean Sea and two locations in the eastern Atlantic (Table 1

126 and Fig. 1a,b) were obtained and stored in $96 \%$ ethanol and kept at $-20{ }^{\circ} \mathrm{C}$. The populations from

127 the western Atlantic sampled above $40^{\circ} \mathrm{N}$ are hereafter referred to as northern locations (ID 1-8),

128 while samples collected below that latitude are referred to as southern locations (ID 9-13).

129 Samples collected from the Mediterranean and eastern Atlantic are referred to as Iberian (ID 14130 16).

131

132 DNA extraction, PCR amplification and sequencing. Total genomic DNA was extracted from 133 caudal fin tissue following a standard Chelex 100 protocol (Walsh et al. 1991). Extraction results 134 were checked by electrophoresis in $0.8 \%$ agarose gel stained with GelRed. Polymerase Chain 135 Reactions (PCR) were conducted in a total volume of $25 \mu \mathrm{L}$, with $1 \mathrm{X}$ buffer, $10 \mathrm{mM}$ dNTPs, $13610 \mathrm{mM}$ of each primer, $1 \mathrm{U}$ Taq Advantage 2 Polymerase mix DNA polymerase (CLONTECH- 
137 TaKaRa), $2 \mu \mathrm{L}$ of DNA and Milli-Q water to the final volume. A fragment of the cytochrome $b$ 138 (cyt $b$ ) gene (1000 base pairs) was amplified with the forward primer GludG-L14724 (Palumbi et 139 al. 1991) and the reverse primer cb6b.h (Martin \& Bermingham 1998). PCR amplification 140 consists of an initial 4 min denaturation step at $95^{\circ} \mathrm{C}$, followed by 40 cycles of 1 min at $94^{\circ} \mathrm{C}$ 141 (denaturation), $1 \mathrm{~min}$ at $50^{\circ} \mathrm{C}$ (annealing) and $1.5 \mathrm{~min}$ at $72{ }^{\circ} \mathrm{C}$ (extension), and a 5 min final 142 extension step. When amplification was not successful the following profile was used: initial 3 143 min denaturation step at $95{ }^{\circ} \mathrm{C}$, followed by 32 cycles of denaturation for $30 \mathrm{~s}$ at $95^{\circ} \mathrm{C}$, annealing 144 for $30 \mathrm{~s}$ at $54{ }^{\circ} \mathrm{C}$ and extension for $1 \mathrm{~min}$ at $68^{\circ} \mathrm{C}$, and a final extension step for 4 min at $68^{\circ} \mathrm{C}$. 145 PCR products were checked afterwards by electrophoresis in a 1\% agarose gel stained with 146 GelRed. Mitochondrial DNA was purified by ethanol/sodium acetate precipitation (Sambrook \& 147 Russel 2001). Its purity and quantity were analysed using a NanoDrop1000 spectrophotometer 148 (Thermo Fisher Scientific, USA). Sequencing was performed on an ABI 3130x1 capillary 149 sequencer (Applied Biosystems - CCMAR, Portugal) using the forward primer from the PCR 150 amplification (GludG-L14724).

151

152 Genetic analysis. Cyt $b$ sequences were aligned and manually checked using the software 153 Geneious v4.8.2 (Biomatters, Ltd., Auckland, New Zealand). The number of haplotypes $(n)$, 154 number of private haplotypes $\left(n_{p}\right)$, and the haplotype $(h)$ (Nei \& Tajima 1981) and nucleotide 155 diversities $(\pi)$ (Nei 1987) were calculated for each location using the DNAsP v5.10.1 (Librado \& 156 Rozas 2009). All sequences were uploaded to GenBank (MH809691 - MH809938). To represent 157 the phylogeographic relationships among haplotypes, a haplotype network was constructed using 158 the Median Joining algorithm implemented in NETWORK v5.0 (Bandelt et al. 1999, fluxus159 engineering.com).

160 We used two approaches to infer the most probable source area of the introduced Iberian 161 populations within the native range of $F$. heteroclitus: (1) the geographical distribution of 162 haplotypes in native populations, and (2) the phylogeographical relationships among haplotypes. 163

164 Ecological niche modelling. To explore the potential spread of $F$. heteroclitus within European 165 waters beyond its currently known locations we used an ecological niche model. We selected the 166 interactive AquaMaps system in FISHBASE (www.fishbase.org). Using observed locations of 167 adults to construct a range of acceptable environmental conditions within which a species can 
168 exist, this model uses a c-squares distribution modelling approach (Rees 2003) to predict the

169 probability of occurrence of the adult fish for a particular location, possessing specific

170 environmental parameters. While this is normally computed just within the native range of a

171 species it can be extended within the interactive system to consider all possible locations, and the

172 associated probability of occurrence linked to the location's mean environmental state if the

173 species was able to reach that region. The basic statistical approach is given in Kaschner et al.

174 (2006) and the AquaMaps version is described in Kesner-Reyes et al. (2012). Another ecological

175 niche model, based on maximum entropy principles (MAXENT, Phillips \& Dudík 2008), was

176 also tested using environmental parameters of sea surface temperature (SST) and sea surface

177 salinity (SSS), but the specialist ecological substrate niche of $F$. heteroclitus led to poor solutions

178 for range prediction using ENM. This latter approach is therefore not considered further here.

179 A set of favourable and extreme environmental conditions compatible with the native

180 occurrence of $F$. heteroclitus is automatically specified by AquaMaps, relying heavily on Page

181 and Burr (2011). It includes parameter ranges for water depth, SST, SSS, primary production

182 rates and sea-ice cover, leading to probabilities of occurrence exceeding 0.6 along the whole

183 eastern seaboard of North America from South Carolina to the Canadian Maritime Provinces

184 south of the Gulf of St. Lawrence. This matches well to the known range (Page \& Burr 2011).

185 However, the long-term survival of $F$. heteroclitus in two Iberian estuaries has implications for

186 extending the extreme salinity level that this species can tolerate beyond that automatically

187 specified. The extreme salinity tolerance has therefore been raised to $39.6 \mathrm{psu}$, compared to the

188 automatic 36.47 psu initially prescribed by AquaMaps, consistent with the values found for the

189 Ria Formosa (Cristina et al. 2016). In addition, the sea-ice variable has been excluded from

190 constraining the AquaMaps solution, as this is not relevant to the area being considered in this

191 study, and also the primary production variable, as coastal environments satisfy the automatic

192 requirement almost uniformly. The environmental variables used for the AquaMaps simulation

193 shown here are given in Table 2.

194 AquaMaps was re-run with these environmental constraints and using the combined

195 occurrence data from the native range, along the North American eastern seaboard, and the two

196 Iberian sites of Ria Formosa and the Ebro River Delta. There is no change to the North American

197 predictions, so here we concentrate only on those for European waters. The occurrence of $F$.

198 heteroclitus was further constrained to coastal zones with the muddy benthic habitats in which $F$. 
199 heteroclitus is found. These are defined as the coastal fine muds to muddy sands benthic

200 environments of the EMODnet Seabed Habitats project (www.emodnet-seabedhabitats.eu).

201 These environments are formally defined by Long (2006), but basically include sediments with

202 more than a $10 \%$ mud component.

203

204

205

206

207

208

209

210

211

212

213

214

215

216

217

218

219

220

221

222

223

224

225

226

227

228

229

\section{Results}

Data analysis on the sampled specimens resulted in cyt $b$ sequences with a final length of 700 base pairs (bp), which comprised 77 (11\%) polymorphic sites and 32 (41.6\%) parsimonyinformative sites. These polymorphisms defined 70 haplotypes, of which $62(88.6 \%)$ are private haplotypes (present in one location only) and 55 (78.6\%) are singletons (present in one individual only). Overall haplotype diversity was high $(0.74 \pm$ SD 0.03$)$, ranging from null in Iberia (ID 14-16) to 0.93 in Tuckerton (ID 9) and Roanoke Island (ID 12), whereas mean nucleotide diversity was low $(0.26 \% \pm \mathrm{SD} 0.06 \%)$ ranging from null diversity in Iberia to $0.91 \%$ in Woods Hole (ID 4) (Table 1 and Fig. 2).

The most abundant haplotype in North American locations is shared by $50.4 \%(N=125)$ of the individuals and is present in all northern group locations, in one southern location and in all Iberian locations (Fig. 1c). This is the only haplotype detected in the invasive range of the species (Faro, Cádiz and Ebro Delta). The second most frequent haplotype in North American locations is shared by $9.7 \%(N=24)$ individuals in six locations, although in higher frequency in the southern group locations. Two other haplotypes were found in 3.2\% $(N=8)$ and in $2.4 \%(N=$ 6) of the individuals from two locations. All other haplotypes were present in five or less individuals and in less than three locations (Fig.1c).

The cyt $b$-based haplotype network (Fig. 3) displays two haplogroups separated by 9 mutational steps. Haplogroup A is constituted by all eight northern group locations (Bridgewater to Red Bank, ID 1-8), two individuals from the southern group (Suffolk, ID 11) and by the Iberian locations (Faro to Ebro Delta, ID 14-16). Haplogroup B is formed by all the other individuals from all southern locations (Tuckerton to Skidaway Island, ID 9-13) and includes eight individuals from northern locations: one from Bridgewater (ID 1) and seven from Woods Hole (ID 4). Overall, both haplogroups display star-like configurations with different levels of complexity. The northern haplogroup (A) is simpler with $90 \%$ of the haplotypes separated by a 
230 single mutation, while the southern haplogroup (B) is more complex, with 3 mini-stars

231 interconnected by one mutation each, and haplotypes separated by up to five mutations. The

232 haplotype found in the Iberian Peninsula belongs to the northern haplogroup.

233 The AquaMaps ENM shows that the basic environment for the spread of $F$. heteroclitus

234 is fundamentally favourable (probability $>0.75$ ), along much of the Atlantic coastline of western

235 Europe (Fig. 4). Conditions become less favourable in the Mediterranean, although the Alboran

236 Sea, east of the Strait of Gibraltar, has an environment that is at least acceptable

237 (probability $>0.25$ ). There are also a small number of estuaries along the Balearic Sea coastline of

238 NE Spain and southern France where acceptable conditions are also found. The main constraint

239 on spread of $F$. heteroclitus, however, is the absence of muddy benthic habitats. The latter are

240 shown by the solid lines in Fig. 4. All the European coastlines within the zone where $F$.

241 heteroclitus is now found have a small number of muddy estuaries separated by long stretches of

242 unsuitable, rockier, benthic habitats. It is only along the environmentally unfavourable North

243 African coast that extensive areas of favourable habitats are found. The ENM shows

244 conclusively that lateral spread of $F$. heteroclitus along European shorelines by natural means is

245 very unlikely.

246

247

248

249 Discussion

250 Results revealed the presence of a single haplotype common to all individuals in the Iberian

251 Peninsula. This haplotype is the most abundant in the northern group of the native distribution,

252 indicating the most probable origin of the invasion. We posit as the most likely introduction

253 vector the aquarium trade and propose, through a combination of DNA and ENM evidence, that

254 the Ebro Delta colonization results from an independent human-mediated secondary

255 introduction. Before addressing the main interpretations and conclusions of these results, one

256 main caveat must be addressed. Successful understanding of the invasion pathway relies on (1)

257 comparable genetic data retrieved from an adequate number of sampled individuals throughout

258 the entire native range, (2) presence of genetic clines within the native populations and (3) the

259 use of adequate molecular markers (Geller et al. 2010). While the first two points are fulfilled for 
$260 F$. heteroclitus, the use of a single mitochondrial DNA marker constitutes the main caveat of this

261 study. Mitochondrial DNA has been a widely used molecular marker in population genetics

262 studies (Ballard \& Whitlock 2004). Nevertheless, the use of high variable nuclear markers, such

263 as microsatellites, provides an opportunity to perform assignment tests based on their multiple-

264 locus genotypes, to test for recent reductions in population sizes and to estimate effective

265 population sizes. However, previously published studies show relatively low microsatellite

266 genetic variation in the northern group (Duvernell et al. 2008). Single nucleotide polymorphisms

267 (SNPs, Morin et al. 2004), extend the previously referred analytical possibilities improving their

268 statistical power because of the sheer number of existing loci genome wide.

269

270

271 Genetic diversity

272 The presence of a single haplotype common to all $F$. heteroclitus sampled in the Iberian

273 Peninsula lends support to the hypothesis of an extremely recent introduction of the species

274 which has not allowed the accumulation of mutations at the mtDNA level, and with a single

275 introduction event composed by a very small number of individuals (Roman \& Darling 2007).

276 Theoretically, invasive species are expected to suffer loss of genetic variation since the new

277 established populations are often based on a few individuals, which by definition, have lower

278 genetic diversity than the native source populations (Dlugosch \& Parker 2008). The single-

279 haplotype characteristic can be found in other invasive species, such as Equulites elongatus, the

280 slender pony fish (Sakinan et al. 2017); Cercopagis pengoi, the fishhook waterflea, a planktonic

281 cladoceran crustacean (Cristescu et al. 2001); Corbicula fluminea, the Asian clam (Gomes et al.

282 2016) and Didemnum perlucidum, a sea squirt (Dias et al. 2016). However, many successful

283 invasive species do not display significant erosion of genetic diversity (Dlugosch \& Parker

284 2008). For example, in a recent review of the literature on European seas invasion genetics, in

$28554 \%$ of studies that compared the genetic diversity between introduced species and their native

286 range, 74\% reported comparable levels of diversity between them, while only $23 \%$ displayed a

287 reduction in the genetic diversity of introduced species, and the remaining $2 \%$ showed an

288 increase in diversity (Rius et al. 2014).

289 


\section{Population sources}

291 We identified a single Iberian haplotype present in all northern populations in high frequency

292 (between 47 and 93\%) and in two individuals in Suffolk, one of the southern locations.

293 According to our results, the northern group is the most probable source of the founder

294 individuals, which corresponds to the natural range of the subspecies $F$. h. macrolepidotus.

295 However, we cannot definitely exclude Suffolk as a presumptive population source. The absence

296 of genetic diversity in the Iberian Peninsula populations prevents the precise determination of the

297 putative source population. The low spatial resolution of our data arises from the lack of genetic

298 variability in the invasive range, rather than insufficient sampling of $F$. heteroclitus individuals

299 in the Iberian Peninsula or in its native range (Muirhead et al. 2008).

300 Nevertheless, our findings are consistent with two previous studies on the origin of invasive

301 individuals found in the Guadalquivir. First, based on mtDNA restriction fragment length

302 polymorphisms (RFLP) (Fernández-Pedrosa et al. 1996) reported the presence of two

303 haplotypes: the most abundant corresponding to the northern haplotype 1, dominant between

304 Maine and Nova Scotia in North America; the other haplotype did not match any of the sampled

305 native haplotypes and we found no evidence of its presence in the present study, using a larger

306 number of individuals. It was previously suggested to be either a native unsampled haplotype or

307 an endemic haplotype from Iberia, which is rather unlikely due to its recent invasion

308 (Fernández-Pedrosa et al. 1996) and total absence of records in the area. Although there are no

309 reports of hybridization between $F$. heteroclitus and any of the Spanish endemic species, the

310 presence of a new haplotype could nonetheless be due to hybridization (Rius et al. 2014).

311 Secondly, a study based on cyt $b$ sequences (Bernardi et al. 1995) concluded the individuals from

312 the Guadalquivir originated in the region between Maine and Nova Scotia. While we cannot

313 discount the possibility of a few rogues from Suffolk being responsible for the invasion, the

314 weight of probability falls heavily on the side of Maine to Nova Scotia origin.

\section{Introduction vector}

317 Since it was first recorded in Iberian saltmarshes, several studies linked F. heteroclitus

318 introduction to different vectors. The aquarium trade has been suggested as the most important

319 vector responsible for the introduction of this species (e.g. Gozlan 2010 and references therein),

320 followed by ballast water (Fernández-Delgado 2010; García-Revillo \& Fernández-Delgado 
321 2009), biological control (Gozlan 2010) and unknown origins (Fernández-Delgado 1989;

322 Gutiérrez-Estrada et al. 1998). We posit that the introduction via the aquarium trade or animal

323 acquisition for scientific purposes is the most probable scenario responsible for the establishment

324 of the first individuals in Iberia, given the genetic results obtained.

325 It is well known that vessels can transport large numbers of organisms from several

326 species at the same time in their ballast water (Gollasch 2007). Since there are countless vessels

327 active around the world (e.g., Kaluza et al. 2010), ballast water-mediated transport allows the

328 possibility of multiple introduction events, each with large groups of individuals (Hulme 2009).

329 Considering such large groups usually comprise higher genetic diversity than fewer individuals

330 alone, the assemblages transported are likely to display levels of genetic diversity similar to the

331 levels found within their native range (Wilson et al. 2009). Our findings, however, suggest that

332 this was not the introduction vector responsible for the spread of the species; in contrast to the

333 expectation of similar levels of genetic diversity between the native and invasive range, the

334 Iberian locations display a strong founder effect, with all samples sharing a single haplotype.

335 Similarly to ballast water, the aquarium and ornamentals trade transport many species at a

336 global scale (Padilla \& Williams 2004). For instance, at least 19\% of the invasive fishes found in

337 the Iberian Peninsula were introduced via the aquarium trade (Maceda-Veiga et al. 2013).

338 However, there are two main differences between introductions that follow ballast water or the

339 aquarium trade. First, each introduction event after aquarium release is likely to comprise a small

340 number of individuals (Duggan et al. 2006). Thus, even though this vector may be responsible

341 for the establishment of several non-native species (Padilla \& Williams 2004), multiple

342 introductions would be necessary for an invasive species to display high genetic diversity

343 (Roman \& Darling 2007). Secondly, the individuals released by aquarists are usually adults of

344 higher fitness, which makes them better adapted to survive in a natural environment (Padilla \&

345 Williams 2004). Thus, not only are the $F$. heteroclitus invasive genetic diversity and structure

346 consistent with an introduction of a low number of individuals via the aquarium trade, but it is

347 also plausible that a few resistant individuals would manage to survive, reproduce and colonize

348 the environment in which they were released.

349

\section{Human mediated introduction in the Ebro Delta}


351 Although the absence of genetic structure within Iberia limits possible insights into the invasion

352 pathway, our data support the hypothesis of a human-mediated introduction episode responsible

353 for the establishment of $F$. heteroclitus in the Ebro Delta, as previously suggested by Gisbert and

354 López (2007) based on taxonomic identification. The hypothesis of a long-distance colonization

355 via natural dispersal is quite unlikely, as is strongly shown by the ENM analysis (Fig. 4).

356 According to a review of the geographical distribution of Cyprinodontiformes along the

357 northeastern coast of Spain by (García-Berthou \& Moreno-Amich 1991), no F. heteroclitus

358 individuals were found at the Ebro Delta in 1989; the first record of the species was only

359 registered 16 years later by Gisbert and López (2007). Thus, we estimate the date of

360 establishment in the Ebro Delta ranges between 12 and 28 years ago. Assuming this estimate is

361 correct, a natural colonization hypothesis implies individuals would have taken roughly two

362 decades to travel more than $1000 \mathrm{~km}$ from their southernmost limit located in the Guadalquivir

363 saltmarshes (Gutiérrez-Estrada et al. 1998) to the Ebro Delta. However, when compared with the

364 natural colonization of the Ria Formosa, this hypothesis seems quite improbable. While $F$.

365 heteroclitus was never collected during sampling events that happened in the Ria Formosa

366 between 1980 and 2006 (França et al. 2009; Ribeiro et al. 2006; Ribeiro et al. 2008), analysis of

367 prey remains left by Little Terns (Sterna albifrons) in the salt-pans and barrier islands revealed

368 this prey species was present in the salt-pans and adjacent channels at least since 2002 (Catry et

369 al. 2006). Although this may sound contradictory, F. heteroclitus could in fact have been present

370 in the Ria Formosa in specific unsampled locations or at extremely low densities, avoiding

371 capture. Nonetheless, assuming that colonization happened around 2002, it seems that $F$.

372 heteroclitus took no more than ca. 20 years to travel around $50 \mathrm{~km}$ from the Guadiana Delta,

373 where it was first detected in 1976 (Coelho et al. 1976)\}, despite both areas being on a stretch of

374 coast with a favourable benthic habitat (Fig. 4). This estimate indicates that if the Ebro

375 colonization happened via natural dispersal, it must have happened 20 times faster than the

376 natural colonization of the Ria Formosa. Given that $F$. heteroclitus has very low dispersal

377 abilities (e.g., Fritz et al. 1975; Lotrich 1975), the natural colonization scenario for the Ebro 378 seems unlikely.

379 Furthermore, if establishment in the Ebro Delta followed a natural range expansion one

380 would expect to find several established populations between the Barbate marshes in the

381 Guadalquivir, its southernmost location (Gutiérrez-Estrada et al. 1998), and the Ebro Delta. 
382 However, no invasive individuals were found at Mar Menor, a coastal lagoon with suitable 383 conditions for successful establishment (Pérez-Ruzafa et al. 2006), located midway between the 384 Guadalquivir and the Ebro Delta.

385 Finally, the Strait of Gibraltar would represent a barrier to dispersal and gene flow, 386 limiting $F$. heteroclitus natural range expansion towards the Mediterranean Sea (Doadrio et al. 387 2002) because of the strong currents prevailing in the area and the absence of suitable habitats. 388 Although uncertain for $F$. heteroclitus, this movement has already been documented for two 389 other Iberian toothcarps, where restricted gene flow in this region led to speciation of the 390 Aphanius iberus in the Mediterranean Iberian coast and Aphanius baeticus in the southwestern 391 Atlantic Spanish coast (Doadrio et al. 2002).

392

393 Ecological niche modelling

394 Conditions for the spread of $F$. heteroclitus are limited by the existence of benthic muddy 395 saltmarsh environments compatible with the species' ecological requirements. These habitats are only found near major estuaries or lagoons areas along the Atlantic and western Mediterranean

397

398

399

400

401

402

403

404

405

406

407

408

409

410

411

412

\section{2} coastlines. The exception to this is along the North African coast (Fig. 4), where such environments are more continuous, although other aspects may be less favourable there, as suggested by the rapid decline in occurrence probability eastwards. The consequence of this benthic habitat constraint is to make along-shore colonisation unlikely in most areas, suggesting that any such sudden expansion would need to be aided by human release.

\section{Conclusions}

Fundulus heteroclitus invasive Iberian populations revealed the presence of a single cyt $b$ haplotype common to all individuals. This haplotype is predominant in the northern group of the native distribution, and although we cannot determine which exact location was at the origin of the introduced individuals, one can identify the northern end of range as the source of the introduction. The lack of genetic diversity is consistent with a strong founder effect at the origin of $F$. heteroclitus in Iberia. Although there is no direct evidence, we infer that the most likely vector was the aquarium trade, and that the Ebro Delta colonization results from a humanmediated secondary introduction isolated from the rest of Iberia. Considering the tolerance of the 
413 species to high salinity, its temperature range, and the significant amount of colonized area in the

414 Iberian southern region, we predict that $F$. heteroclitus will most likely keep on expanding its

415 invasive range until it faces unfavourable environmental conditions. However, natural

416 colonisation in Europe will be strongly restricted by its restrictive requirement for suitable

417 muddy, benthic habitats and human-mediated transfer is its most likely means of range

418 expansion.

419

420

421 Acknowledgements

422 Occurrence data for the AquaMaps modelling was provided through the AquaMaps website

423 (www.aquamaps.org), and the model simulation was run through the same site. Information on

424 seabed habitats contained in this study has been derived from data that is made available under

425 the European Marine Observation Data Network (EMODnet) Seabed Habitats project

426 (http://www.emodnet-seabedhabitats.eu/), funded by the European Commission's Directorate-

427 General for Maritime Affairs and Fisheries (DG MARE). Authors are thankful to N. Franch and

428 J.M. Queral (Parc Natural del Delta de l'Ebre, PNDE) for providing animals from the Ebro River 429 Delta.

430

431

432

433

434

435

436

437

438

439

440

441

442

443

444

445

446

447

\section{References}

Adams SM, Lindmeier JB, and Duvernell DD. 2006. Microsatellite analysis of the phylogeography, Pleistocene history and secondary contact hypotheses for the killifish, Fundulus heteroclitus. Molecular Ecology 15:1109-1123. https://doi.org/10.1111/j.1365294x.2006.02859.x

Ballard JWO, and Whitlock MC. 2004. The incomplete natural history of mitochondria. Molecular Ecology 13:729-744. https://doi.org/10.1046/j.1365-294X.2003.02063.x

Bandelt HJ, Forster $P$, and Röhl A. 1999. Median-joining networks for inferring intraspecific phylogenies. Molecular Biology and Evolution 16:37-48. https://doi.org/10.1093/oxfordjournals.molbev.a026036

Bax N, Williamson A, Aguero M, Gonzalez E, and Geeves W. 2003. Marine invasive alien species: a threat to global biodiversity. Marine Policy 27:313-323.

https://doi.org/10.1016/s0308-597x(03)00041-1

Bernardi G, Fernandez-Delgado C, Gomez-Chiarri M, and Powers DA. 1995. Origin of a Spanish population of Fundulus heteroclitus inferred by cytochrome b sequence analysis. Journal of Fish Biology 47:737-740. https://doi.org/10.1111/j.1095-8649.1995.tb01939.x 
448

449

450

451

452

453

454

455

456

457

458

459

460

461

462

463

464

465

466

467

468

469

470

471

472

473

474

475

476

477

478

479

480

481

482

483

484

485

486

487

488

489

490

Bernardi G, Sordino P, and Powers DA. 1993. Concordant mitochondrial and nuclear DNA phylogenies for populations of the teleost fish Fundulus heteroclitus. Proceedings of the National Academy of Sciences 90:9271-9274. https://doi.org/10.1073/pnas.90.20.9271

Bigelow HB, and Schroeder WC. 1953. Fishes of the Gulf of Maine. Available at https://archive.org/stream/fishesofgulfofma1953bige/fishesofgulfofma1953bige djvu.t xt (accessed 17 June 2017).

Bock DG, Caseys C, Cousens RD, Hahn MA, Heredia SM, Hübner S, Turner KG, Whitney KD, and Rieseberg LH. 2015. What we still don't know about invasion genetics. Molecular Ecology 24:2277-2297. https://doi.org/10.1002/9781119072799.ch20

Catry T, Ramos JA, Paiva VH, Martins J, Almeida A, Palma J, Andrade PJ, Peste F, Trigo S, and LuÍs A. 2006. Intercolony and annual differences in the diet and feeding ecology of little tern adults and chicks in Portugal. The Condor 108:366-376. https://doi.org/10.1650/0010-5422(2006)108[366:IAADIT]2.0.CO;2

Coelho M, Gomes J, and Re PB. 1976. Valencia hispanica, a new fish to Portugal. Archivos do Museu Bocage (2 a Série) Notas e suplementos:5.

Cristescu ME. 2015. Genetic reconstructions of invasion history. Molecular Ecology 24:22122225. https://doi.org/10.1111/mec.13117

Cristescu MEA, Hebert PDN, Witt JDS, Maclsaac HJ, and Grigorovich IA. 2001. An invasion history for Cercopagis pengoi based on mitochondrial gene sequences. Limnology and Oceanography 46:224-229. https://doi.org/10.4319/lo.2001.46.2.0224

Cristina S, Sequeira A, Newton A, JG F, and Icely J. 2016. ECASA Study Site Report Ria Formosa coastal lagoon, Portugal. $\mathrm{p} 48$.

Dias JP, Rocha R, Godwin S, Tovar-Hernández MA, Delahoz MV, McKirdy S, de Lestang P, McDonald JI, and Snow M. 2016. Investigating the cryptogenic status of the sea squirt Didemnum perlucidum (Tunicata, Ascidiacea) in Australia based on a molecular study of its global distribution. Aquatic Invasions 11:239-245. https://doi.org/10.3391/ai.2016.11.3.02

Dlugosch KM, and Parker IM. 2008. Founding events in species invasions: genetic variation, adaptive evolution, and the role of multiple introductions. Molecular Ecology 17:431449. https://doi.org/10.1111/j.1365-294x.2007.03538.x

Doadrio I, Carmona JA, and Fernandez-Delgado C. 2002. Morphometric study of the Iberian Aphanius (Actinopterygii, Cyprinodontiformes), with description of a new species. Folia Zoologica 51:67-79.

Duggan IC, Rixon CAM, and Maclsaac HJ. 2006. Popularity and propagule pressure: determinants of introduction and establishment of aquarium fish. Biological Invasions 8:377-382. https://doi.org/10.1007/s10530-004-2310-2

Duvernell DD, Lindmeier JB, Faust KE, and Whitehead A. 2008. Relative influences of historical and contemporary forces shaping the distribution of genetic variation in the Atlantic killifish, Fundulus heteroclitus. Molecular Ecology 17:1344-1360. https://doi.org/10.1111/j.1365-294x.2007.03648.x

Elvira B, and Almodóvar A. 2001. Freshwater fish introductions in Spain: facts and figures at the beginning of the 21st century. Journal of Fish Biology 59:323-331.

https://doi.org/10.1111/j.1095-8649.2001.tb01393.x 
491 Estoup A, and Guillemaud T. 2010. Reconstructing routes of invasion using genetic data: why,

492

493

494

495

496

497

498

499

500

501

502

503

504

505

506

507

508

509

510

511

512

513

514

515

516

517

518

519

520

521

522

523

524

525

526

527

528

529

530

531

532

533 how and so what? Molecular Ecology 19:4113-4130. https://doi.org/10.1111/j.1365294x.2010.04773.x

Fernández-Delgado C. 1989. Life-history patterns of the salt-marsh killifish Fundulus heteroclitus (L.) introduced in the estuary of the Guadalquivir River (South West Spain). Estuarine, Coastal and Shelf Science 29:573-582. https://doi.org/10.1016/0272-7714(89)90011-5

Fernández-Delgado C. 2010. Especies introducidas en Andalucía: El caso de los peces. Especies exóticas invasoras en Andalucía Talleres provinciales 2004-2006: Consejería de Medio Ambiente. Junta de Andalucía, 132-137.

Fernández-Pedrosa V, Latorre A, and González A. 1996. Evidence from mtDNA RFLP analysis for the introduction of Fundulus heteroclitus to southwestern Spain. Journal of Fish Biology 48:1278-1282. https://doi.org/10.1111/j.1095-8649.1996.tb01822.x

França S, Costa MJ, and Cabral HN. 2009. Assessing habitat specific fish assemblages in estuaries along the Portuguese coast. Estuarine, Coastal and Shelf Science 83:1-12. https://doi.org/10.1016/j.ecss.2009.03.013

Fritz ES, Meredith WH, and Lotrich VA. 1975. Fall and winter movements and activity level of the mummichog, Fundulus heteroclitus, in a tidal creek. Chesapeake Science 16:211-215. https://doi.org/10.2307/1350898

Galil BS, Marchini A, Occhipinti-Ambrogi A, Minchin D, Narščius A, Ojaveer H, and Olenin S. 2014. International arrivals: widespread bioinvasions in European Seas. Ethology Ecology \& Evolution 26:152-171. https://doi.org/10.1080/03949370.2014.897651

García-Berthou E, and Moreno-Amich R. 1991. New records of Aphanius iberus (Pisces: Cyprinodontidae) and review of the geographical distribution of cyprinodontiform fishes in Catalonia (NE-Spain). Scientia gerundensis 17:69-76.

García-Revillo MG, and Fernández-Delgado C. 2009. La introducción por mar de especies exóticas invasoras a través del agua de lastre de los barcos: el caso de Doñana. Córdoba: UCOPress, Editorial Universidad de Córdoba.

Geller JB, Darling JA, and Carlton JT. 2010. Genetic perspectives on marine biological invasions. Annual Review of Marine Science 2:367-393. https://doi.org/10.1146/annurev.marine.010908.163745

Gisbert E, and López MA. 2007. First record of a population of the exotic mummichog Fundulus heteroclitus (L., 1766) in the Mediterranean Sea basin (Ebro River delta). Journal of Fish Biology 71:1220-1224. https://doi.org/10.1111/j.1095-8649.2007.01579.x

Gollasch S. 2007. Is ballast water a major dispersal mechanism for marine organisms? In: Nentwig W, ed. Biological Invasions: Springer-Verlag Berlin Heidelberg, 49-57.

Gomes C, Sousa R, Mendes T, Borges R, Vilares P, Vasconcelos V, Guilhermino L, and Antunes A. 2016. Low genetic diversity and high invasion success of Corbicula fluminea (Bivalvia, Corbiculidae)(Müller, 1774) in Portugal. PLOS ONE 11:e0158108. https://doi.org/10.1371/journal.pone.0158108

Gonçalves R, Teodósio M, Cruz J, Ben-Hamadou R, Correia A, and Chícharo L. 2017. Preliminary insight into winter native fish assemblages in Guadiana estuary salt marshes coping with environmental variability and non-indigenous fish introduction. Fishes 2.

https://doi.org/10.3390/fishes2040019 
534 González-Vilaseñor LI, and Powers DA. 1990. Mitochondrial-DNA restriction-site polymorphisms

535

536

537

538

539

540

541

542

543

544

545

546

547

548

549

550

551

552

553

554

555

556

557

558

559

560

561

562

563

564

565

566

567

568

569

570

571

572

573

574

575 in the teleost Fundulus heteroclitus support secondary intergradation. Evolution 44:2737. https://doi.org/10.1111/j.1558-5646.1990.tb04277.x

Gozlan RE. 2010. The cost of non-native aquatic species introductions in Spain: fact or fiction? Aquatic Invasions 5:231-238. https://doi.org/10.3391/ai.2010.5.3.02

Gutiérrez-Estrada JC, Prenda J, Oliva F, and Fernández-Delgado C. 1998. Distribution and habitat preferences of the introduced mummichog Fundulus heteroclitus (Linnaeus) in Southwestern Spain. Estuarine, Coastal and Shelf Science 46:827-835. https://doi.org/10.1006/ecss.1997.0318

Hardy Jr JD. 1978. Development of fishes of the mid-Atlantic Bight: an atlas of egg, larval, and juvenile stages. Volume II. Anguillidae through Syngnathidae.: United States Fish and Wildlife Service. FWS/OBS-78/12.

Hernando J. 1975. Nuevas localidades de Valencia hispanica (Pisces: Cyprinodontidae) en el suroeste de España. Doñana Acta Vertebrata 2:265-267.

Hulme PE. 2009. Trade, transport and trouble: managing invasive species pathways in an era of globalization. Journal of Applied Ecology 46:10-18. https://doi.org/10.1111/j.13652664.2008.01600.x

Kaluza P, Kölzsch A, Gastner MT, and Blasius B. 2010. The complex network of global cargo ship movements. Journal of the Royal Society Interface 7:1093-1103. https://doi.org/10.1098/rsif.2009.0495

Kaschner K, Watson R, Trites A, and Pauly D. 2006. Mapping world-wide distributions of marine mammal species using a relative environmental suitability (RES) model. Marine Ecology Progress Series 316:285-310. 10.3354/meps316285

Kesner-Reyes K, Kaschner K, Kullander S, Garilao C, Baril J, and Froese R. 2012. AquaMaps: algorithm and data sources for aquatic organisms. Available at www. fishbase.org (accessed March 2018).

Kneib RT. 1984. Patterns in the utilization of the intertidal salt marsh by larvae and juveniles of Fundulus heteroclitus (Linnaeus) and Fundulus luciae (Baird). Journal of Experimental Marine Biology and Ecology 83:41-51. https://doi.org/10.1016/0022-0981(84)90116-3

Lawson Handley L-J, Estoup A, Evans DM, Thomas CE, Lombaert E, Facon B, Aebi A, and Roy HE. 2011. Ecological genetics of invasive alien species. BioControl 56:409-428. https://doi.org/10.1007/s10526-011-9386-2

Librado P, and Rozas J. 2009. DnaSP v5: a software for comprehensive analysis of DNA polymorphism data. Bioinformatics 25:1451-1452. https://doi.org/10.1093/Bioinformatics/Btp187

Long D. 2006. BGS detailed explanation of seabed sediment modified folk classification. Keyworth, UK.

Lotrich VA. 1975. Summer home range and movements of Fundulus heteroclitus (Pisces: Cyprinodontidae) in a tidal creek. Ecology 56:191-198. https://doi.org/10.2307/1935311 Maceda-Veiga A, Escribano-Alacid J, de Sostoa A, and García-Berthou E. 2013. The aquarium trade as a potential source of fish introductions in southwestern Europe. Biological Invasions 15:2707. https://doi.org/10.1007/s10530-013-0485-0 
576 Martin AP, and Bermingham E. 1998. Systematics and evolution of lower Central American

577

578

579

580

581

582

583

584

585

586

587

588

589

590

591

592

593

594

595

596

597

598

599

600

601

602

603

604

605

606

607

608

609

610

611

612

613

614

615

616

617

618

619 cichlids inferred from analysis of cytochrome $b$ gene sequences. Molecular Phylogenetics and Evolution 9:192-203. https://doi.org/10.1006/mpev.1997.0461

McKenzie JL, Dhillon RS, and Schulte PM. 2016. Steep, coincident, and concordant clines in mitochondrial and nuclear-encoded genes in a hybrid zone between subspecies of Atlantic killifish, Fundulus heteroclitus. Ecology and Evolution 6:5771-5787. https://doi.org/10.1002/ece3.2324

Millennium Ecosystem Assessment. 2005. Ecosystems and Human Well-being: Biodiversity Synthesis. Available at http://millenniumassessment.org/en/Synthesis.html (accessed 2 August 2017).

Molnar JL, Gamboa RL, Revenga C, and Spalding MD. 2008. Assessing the global threat of invasive species to marine biodiversity. Frontiers in Ecology and the Environment 6:485492. https://doi.org/10.1890/070064

Morin PA, Luikart G, Wayne RK, and the SNP workshop group. 2004. SNPs in ecology, evolution and conservation. Trends in Ecology \& Evolution 19:208-216. https://doi.org/10.1016/j.tree.2004.01.009

Morin RP, and Able KW. 1983. Patterns of geographic variation in the egg morphology of the fundulid fish, Fundulus heteroclitus. Copeia 1983:726-740. https://doi.org/10.2307/1444339

Muirhead JR, Gray DK, Kelly DW, Ellis SM, Heath DD, and Macisaac HJ. 2008. Identifying the source of species invasions: sampling intensity vs. genetic diversity. Molecular Ecology 17:1020-1035. https://doi.org/10.1111/j.1365-294x.2008.03669.x

Nei M. 1987. Genetic distance and molecular phylogeny. In: Ryman N, and Utter FW, eds. Population Genetics \& Fishery Management. Seattle: Washington Sea Grant Program, University of Washington, 193-223.

Nei M, and Tajima F. 1981. DNA polymorphism detectable by restriction endonucleases. Genetics 97:145-163.

Padilla DK, and Williams SL. 2004. Beyond ballast water: aquarium and ornamental trades as sources of invasive species in aquatic ecosystems. Frontiers in Ecology and the Environment 2:131-138. https://doi.org/10.1890/15409295(2004)002[0131:bbwaao]2.0.co;2

Page L, and Burr B. 2011. A field guide to freshwater fishes of North America north of Mexico. Boston: Houghton Mifflin Harcourt.

Palumbi S, Martin A, Romano S, McMillan W, Stice L, and Grabowski G. 1991. The Simple Fool's Guide to PCR, Version 2.0. Honolulu, HI, 96822: University of Hawaii Press.

Pérez-Ruzafa A, Garcia-Charton J, Barcala E, and Marcos C. 2006. Changes in benthic fish assemblages as a consequence of coastal works in a coastal lagoon: The Mar Menor (Spain, Western Mediterranean). Marine Pollution Bulletin 53:107-120. https://doi.org/10.1016/j.marpolbul.2005.09.014

Phillips SJ, and Dudík M. 2008. Modeling of species distributions with Maxent: new extensions and a comprehensive evaluation. Ecography 31:161-175.

Powers DA, and Place AR. 1978. Biochemical genetics of Fundulus heteroclitus (L.). I. Temporal and spatial variation in gene frequencies of $L d h-B, M d h-A, G p i-B$, and Pgm-A. Biochemical Genetics 16:593-607. https://doi.org/10.1007/bf00484222 
620 Powers DA, Ropson I, Brown DC, Van Beneden R, Cashon R, González-Villaseñor LI, and

621

622

623

624

625

626

627

628

629

630

631

632

633

634

635

636

637

638

639

640

641

642

643

644

645

646

647

648

649

650

651

652

653

654

655

656

657

658

659

660

661

662
DiMichele JA. 1986. Genetic variation in Fundulus heteroclitus: geographic distribution. American Zoologist 26:131-144. https://doi.org/10.1093/icb/26.1.131

Rees T. 2003. "C-Squares", a new spatial indexing system and its applicability to the description of oceanographic datasets. Oceanography 16:11-19.

Ribeiro J, Bentes L, Coelho R, Gonçalves JM, Lino PG, Monteiro P, and Erzini K. 2006. Seasonal, tidal and diurnal changes in fish assemblages in the Ria Formosa lagoon (Portugal). Estuarine, Coastal and Shelf Science 67:461-474. https://doi.org/10.1016/j.ecss.2005.11.036

Ribeiro J, Monteiro CC, Monteiro P, Bentes L, Coelho R, Gonçalves JMS, Lino PG, and Erzini K. 2008. Long-term changes in fish communities of the Ria Formosa coastal lagoon (southern Portugal) based on two studies made 20 years apart. Estuarine, Coastal and Shelf Science 76:57-68. https://doi.org/10.1016/j.ecss.2007.06.001

Rius M, Turon X, Bernardi G, Volckaert FA, and Viard F. 2014. Marine invasion genetics: from spatio-temporal patterns to evolutionary outcomes. Biological Invasions 17:869-885. https://doi.org/10.1007/s10530-014-0792-0

Roman J, and Darling JA. 2007. Paradox lost: genetic diversity and the success of aquatic invasions. Trends in Ecology \& Evolution 22:454-464.

https://doi.org/10.1016/j.tree.2007.07.002

Ropson IJ, Brown DC, and Powers DA. 1990. Biochemical genetics of Fundulus heteroclitus (L.). VI. Geographical variation in the gene frequencies of 15 loci. Evolution 44:16-26. https://doi.org/10.1111/j.1558-5646.1990.tb04276.x

Sakinan S, Karahan A, and Ok M. 2017. Integration of DNA barcoding for the initial recordings of Lessepsian fishes: a case study of the Indo-Pacific slender ponyfish Equulites elongatus. Journal of Fish Biology 90:1054-1061. https://doi.org/10.1111/ifb.13207

Sambrook J, and Russel DW. 2001. Molecular cloning: a laboratory manual. Cold Spring Harbor, New York: Cold Spring Harbor Laboratory Press.

Smith MW, Chapman RW, and Powers DA. 1998. Mitochondrial DNA analysis of Atlantic coast, Chesapeake Bay, and Delaware Bay populations of the teleost Fundulus heteroclitus indicates temporally unstable distributions over geologic time. Molecular Marine Biology and Biotechnology 7:79-87.

Walsh PS, Metzger DA, and Higuchi R. 1991. Chelex 100 as a medium for simple extraction of DNA for PCR-based typing from forensic material. BioTechniques 10:506-513. https://doi.org/10.2144/000114018

Williams SL, Davidson IC, Pasari JR, Ashton GV, Carlton JT, Crafton RE, Fontana RE, Grosholz ED, Miller AW, and Ruiz GM. 2013. Managing multiple vectors for marine invasions in an increasingly connected world. BioScience 63:952-966. https://doi.org/10.1525/bio.2013.63.12.8

Wilson JRU, Dormontt EE, Prentis PJ, Lowe AJ, and Richardson DM. 2009. Something in the way you move: dispersal pathways affect invasion success. Trends in Ecology \& Evolution 24:136-144. https://doi.org/10.1016/i.tree.2008.10.007 
Figure 1 (on next page)

Distribution map of localities and haplotypes

Distribution map of localities along the coast of (a) North America, and (b) Iberian Peninsula of Fundulus heteroclitus. Locations and sample details can be found in Table 1. (c) Coloured circles display the distribution of the relative proportions of the cytochromebhaplotypes from each location: the four most common haplotypes, the private haplotypes, and all the other shared, but less frequent haplotypes. 


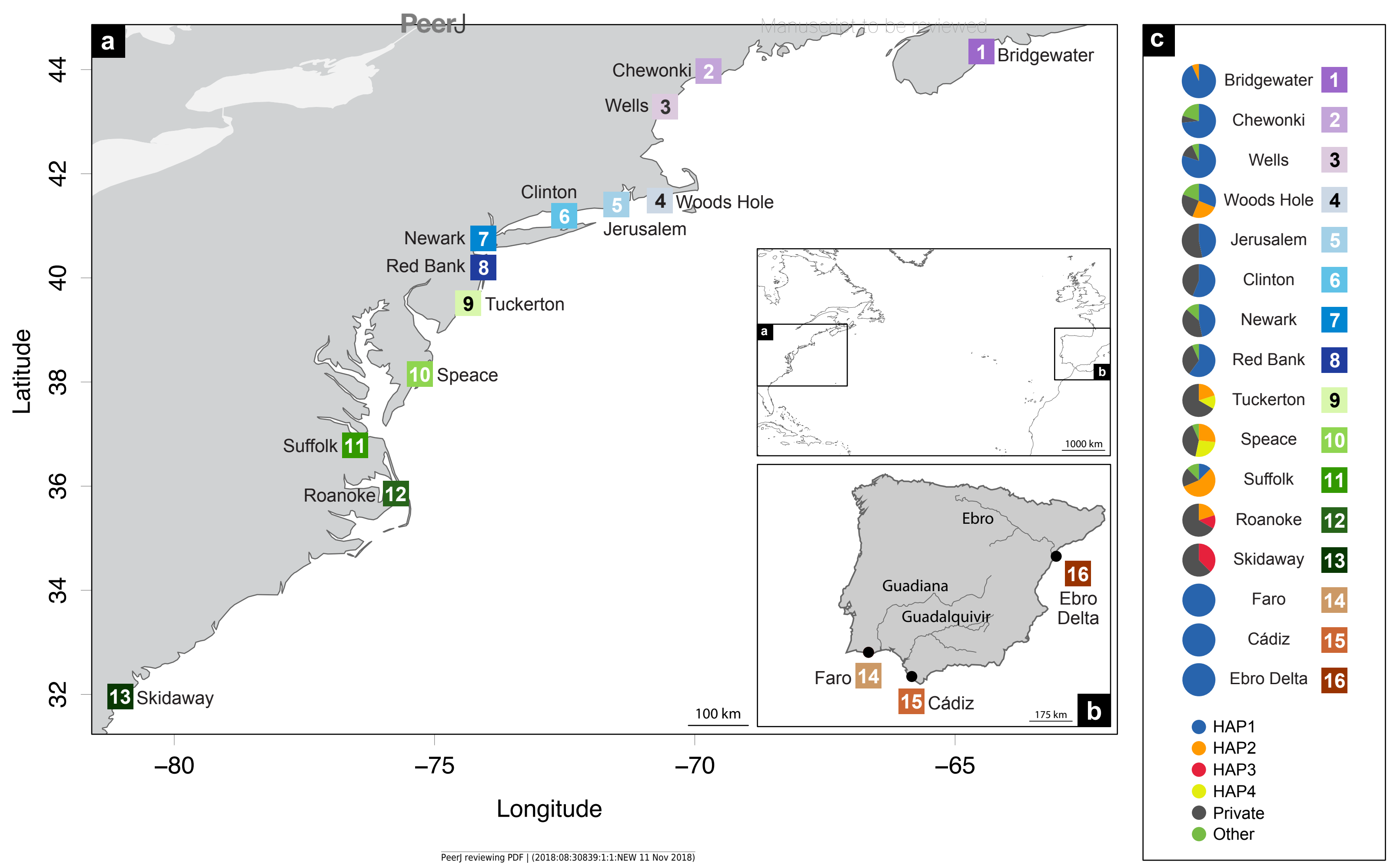


Figure 2 (on next page)

Haplotype and nucleotide diversity

Haplotype and nucleotide diversity of Fundulus heteroclitusfrom all sampled locations.

Abbreviations in the legend are defined in Table 1, and colours are the same as in Fig. 1. 


\section{Figure 3 (on next page)}

Median-joining cytochrome $b$ haplotype network for Fundulus heteroclitus

Median-joining cytochromebhaplotype network for Fundulus heteroclitus. Each circle represents a different haplotype with size proportional to the frequency of the haplotype within the sample. Line length is proportional to the number of mutations between haplotypes. Each colour corresponds to a different location. Colours are the same as in Figure 1. Locations details can be found in Table 1. The two black dots represent putative unsampled haplotypes, and the number in black square shows the number of mutations separating haplogroup A from the haplogroup B. 


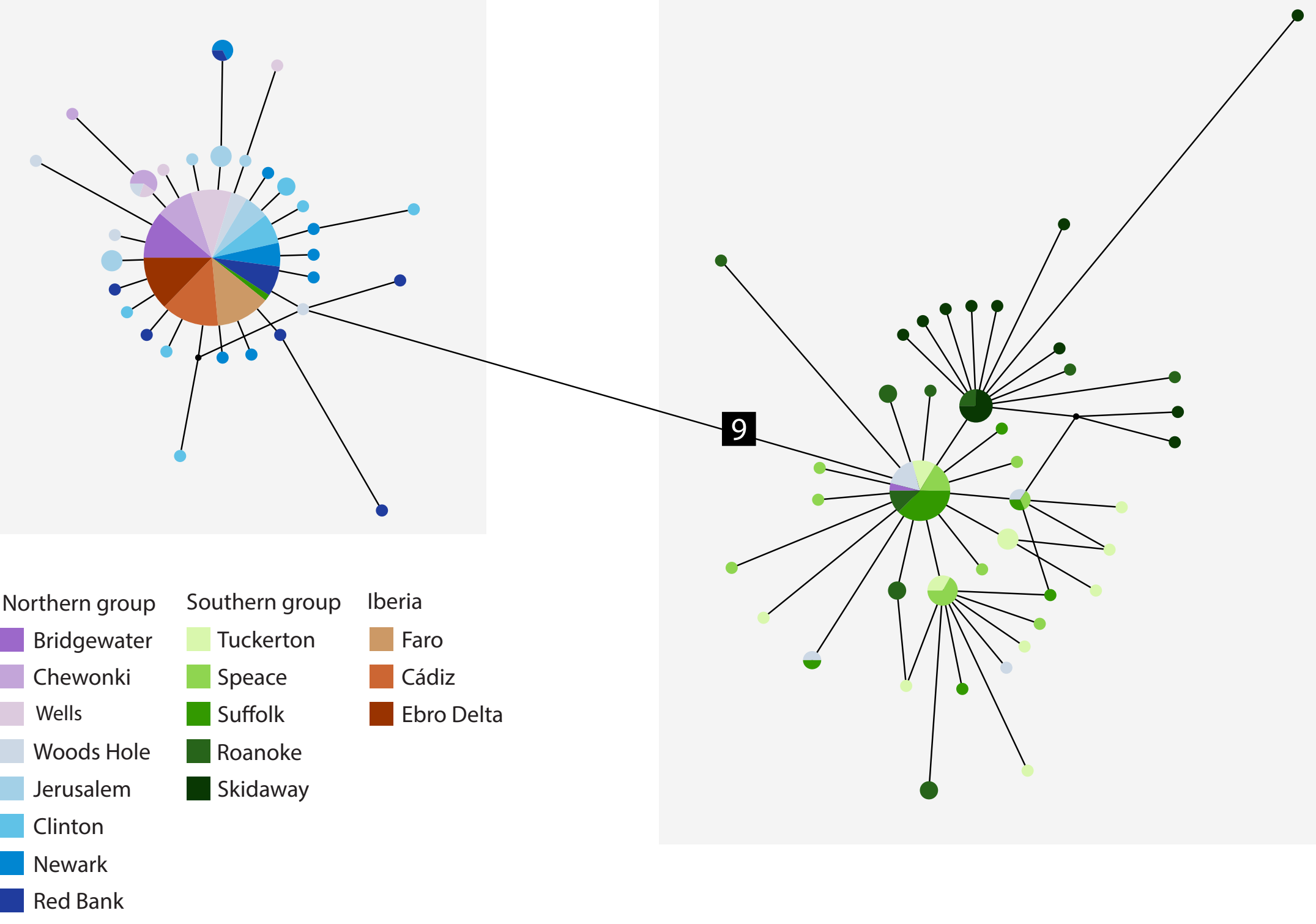


Figure 4 (on next page)

Western European and Mediterranean coastal environments showing AquaMap probabilities of occurrence of $F$. heteroclitus.

Western European and Mediterranean coastal environments showing AquaMap probabilities of occurrence of $F$. heteroclitus. Those areas in bold show coastal seabed habitats with a mud content $>10 \%$. 


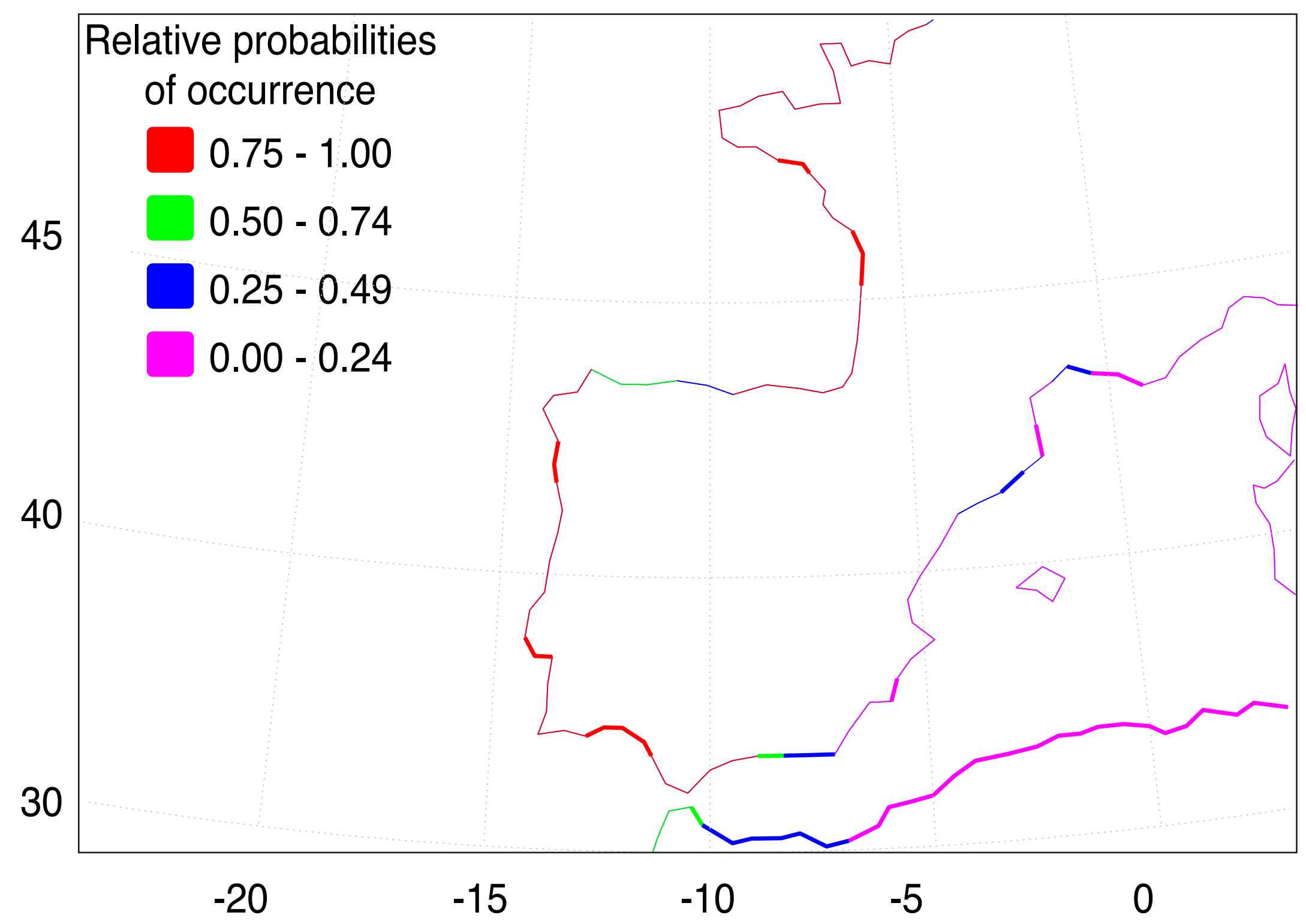




\section{Table $\mathbf{1}$ (on next page)}

Sample details

Sample location, sample abbreviations and summary statistics for a cytochrome bsequence fragment from Fundulus heteroclitus. ID refers to numbers in Fig 1 
1 Table 1 Sample location, sample abbreviations and summary statistics for a cytochrome $b$

2 sequence fragment from Fundulus heteroclitus. ID refers to numbers in Fig 1

3

\begin{tabular}{lllllll}
\hline Location & ID & Code & Latitude / longitude & $n$ & $n_{h}$ & $n_{0}$ \\
\hline Bridgewater & 1 & $\mathrm{HV}$ & $44^{\circ} 22.0^{\prime} \mathrm{N} / 64^{\circ} 31.0^{\prime} \mathrm{W}$ & 15 & 2 & 0 \\
Chewonki & 2 & $\mathrm{CM}$ & $43^{\circ} 57.3^{\prime} \mathrm{N} / 69^{\circ} 43.2^{\prime} \mathrm{W}$ & 15 & 3 & 1 \\
Wells & 3 & $\mathrm{WM}$ & $43^{\circ} 19.2^{\prime} \mathrm{N} / 70^{\circ} 342^{\prime} \mathrm{W}$ & 15 & 4 & 2 \\
Woods Hole & 4 & $\mathrm{WH}$ & $41^{\circ} 31.5^{\prime} \mathrm{N} / 70^{\circ} 40.4^{\prime} \mathrm{W}$ & 16 & 9 & 4 \\
Jerusalem & 5 & $\mathrm{JR}$ & $41^{\circ} 23.1^{\prime} \mathrm{N} / 71^{\circ} 31.5^{\prime} \mathrm{W}$ & 15 & 5 & 4 \\
Clinton & 6 & $\mathrm{CC}$ & $41^{\circ} 15.3^{\prime} \mathrm{N} / 72^{\circ} 32.8^{\prime} \mathrm{W}$ & 16 & 7 & 6 \\
Newark Bay & 7 & $\mathrm{NB}$ & $40^{\circ} 41.2^{\prime} \mathrm{N} / 74^{\circ} 06.7^{\prime} \mathrm{W}$ & 15 & 8 & 6 \\
Red Bank & 8 & $\mathrm{RE}$ & $40^{\circ} 20.9^{\prime} \mathrm{N} / 74^{\circ} 05.0^{\prime} \mathrm{W}$ & 15 & 7 & 5 \\
Tuckerton & 9 & $\mathrm{TN}$ & $39^{\circ} 32.2^{\prime} \mathrm{N} / 74^{\circ} 19.4^{\prime} \mathrm{W}$ & 15 & 10 & 8 \\
Speace & 10 & $\mathrm{SP}$ & $38^{\circ} 09.1^{\prime} \mathrm{N} / 75^{\circ} 17.2^{\prime} \mathrm{W}$ & 15 & 9 & 6 \\
Suffolk & 11 & $\mathrm{CH}$ & $36^{\circ} 51.8^{\prime} \mathrm{N} / 76^{\circ} 28.7^{\prime} \mathrm{W}$ & 16 & 7 & 3 \\
Roanoke Island & 12 & $\mathrm{RI}$ & $35^{\circ} 53.8^{\prime} \mathrm{N} / 75^{\circ} 36.9^{\prime} \mathrm{W}$ & 15 & 9 & 7 \\
Skidaway Island & 13 & $\mathrm{SI}$ & $31^{\circ} 56.8^{\prime} \mathrm{N} / 81^{\circ} 04.2^{\prime} \mathrm{W}$ & 16 & 11 & 1 \\
Faro & 14 & $\mathrm{RF}$ & $37^{\circ} 00.3^{\prime} \mathrm{N} / 07^{\circ} 58.0^{\prime} \mathrm{W}$ & 16 & 1 & 0 \\
Cádiz & 15 & $\mathrm{CD}$ & $36^{\circ} 31.4^{\prime} \mathrm{N} / 06^{\circ} 11.4^{\prime} \mathrm{W}$ & 17 & 1 & 0 \\
Ebro Delta & 16 & $\mathrm{ED}$ & $40^{\circ} 37.38^{\prime} \mathrm{N} / 0^{\circ} 39.44^{\prime} \mathrm{E}$ & 16 & 1 & 0 \\
\hline
\end{tabular}

$4 n$, number of individuals; $n_{h}$, number of haplotypes; $n_{p}$, number of private haplotypes

5

6 


\section{Table 2 (on next page)}

Aquamaps environmental envelope

Aquamaps default environmental envelope for $F$. heteroclitus 
1 Table 2 Aquamaps default environmental envelope for $F$. heteroclitus

\begin{tabular}{lllll}
\hline Variable & Absolute & Preferred & Preferred & Absolute \\
\hline Depth [m] & 0 & 0 & 3 & 5 \\
Sea Surface Temperature & 4.76 & 6.41 & 23.53 & 26.1 \\
Sea Surface Salinity [SSS; & 28.96 & 29.94 & 35.74 & 39.6 \\
\hline
\end{tabular}

2

3 